E3S Web of Conferences 1, 19007 (2013)

DOI: $10.1051 / \mathrm{e} 3$ sconf/20130119007

(c) Owned by the authors, published by EDP Sciences, 2013

\title{
Mercury species in solid matter of dispersion of the Ursk tailing dispersion train (Ursk village, Kemerovo region, Russia)
}

\author{
M. A. Gustaytis ${ }^{1}$, E. V. Lazareva ${ }^{1}$, I. N. Myagkaya ${ }^{1}$, A. A. Bogush ${ }^{1}$ and O. V. Shuvaeva ${ }^{2}$ \\ ${ }^{1}$ Institute of Geology and Minerology SB RAS, Koptyug Pr. 3, Novosibirsk 630090, Russia, E-mail: \\ goustaitis_m@mail.ru \\ ${ }^{2}$ Institute of Inorganic Chemistry SB RAS, Novosibirsk Koptyug Pr. 3, Novosibirsk 630090, Russia E-mail: \\ olga@niic.nsc.ru
}

\begin{abstract}
Mercury species are highly toxic, and methylmercury is the most dangerous for environment and biota. The purpose of this study is to evaluate the distribution of mercury speciations $\left(\mathrm{HgX}_{2}\right.$ (were $\mathrm{X}$ is $\mathrm{O}$, $\mathrm{SO}_{2}{ }^{4-}, \mathrm{Cl}$ and et al.), $\mathrm{CH} 3 \mathrm{Hg}^{+}, \mathrm{HgS}$ ) in diffuse halation high-sulfide waste of piles at the Ursk massive sulfide ore deposits which are being mined since the 1940s. To determine the mercury speciation, the method of thermal analysis with atomic absorption spectrometry as detector was applied.
\end{abstract}

Key Words: mercury speciation, sulfide waste.

\section{Introduction}

One of the primary causes of environmental mercury pollution is gold mining, around which the secondary dispersion halos are formed due to high amounts of toxic components caused by the proximity of the deposit. Such dispersion trains are formed as a result of transportation of metals in dissolved forms in drainage solutions, during the washouts of waste in flood water and rainwater, and the dusting of the tailing's dried part.

The Ursk tailings impoundment (the Ursk village, Kemerovo region, Russia) contains the waste of cyaniding of primary polymetallic copper-zinc sulphide ore and ores of oxidizing zone, which is characterized by high mercury content. The waste is stored in the form of piles; the waste of primary ore consists mostly of pyrite $(50-90 \%)$. The waste is not fixed; during the entire period of the tailing's existence it is routinely diluted by rainwater and flood water. The ravine's swampy territory below the tailings down to the Ur river is covered with the derived waste matter; the area's vegetation has been destroyed due to the acid mine drainage influence. The derived matter lies over the peat, with swamp hassocks still present. Down in the ravine, in the valley of the river Ur, the waste covers the splinters of limestone.

\section{Materials and Methods}

Capillary electrophoresis (Kapel 103P, Lumex, Russia) was used to determine the basic ionic composition of natural waters and drainage solutions. The organic carbon content in poral solutions was determined with the help of an automatic analyzer ("Shumadzu" TOC-VCSH Analyzer). The mineralogical composition of matter was analyzed by the means of X-ray structure analysis, using the DRON-3 device with $\mathrm{CuK} \alpha$-radiation. The grain-size was analyzed using Kachinsky's method, and Turin's method was applied to determine the organic carbon content in the solid matter (Arinushkina E. V., 1970). To determine the total mercury content in natural waters, drainage solutions and pore solutions, we employed the method of cold vapor atomic absorption spectroscopy (CV AAS) after the reduction on gold sorbent ("Perkin Elmer" 3030B) To analyze the distribution of mercury species in the derived solid matter, we used a hybrid method of mercury species definition, combining the thermal analysis and atomic absorption detection; it is based on the difference between vaporization temperatures of various mercury compounds. To perform this, we used the RA- $915^{+}$mercury analyzer (Lumex, Russia) with a RP-91C pyrolytical attachment (Shuvaeva O. V., et al, 2008). 


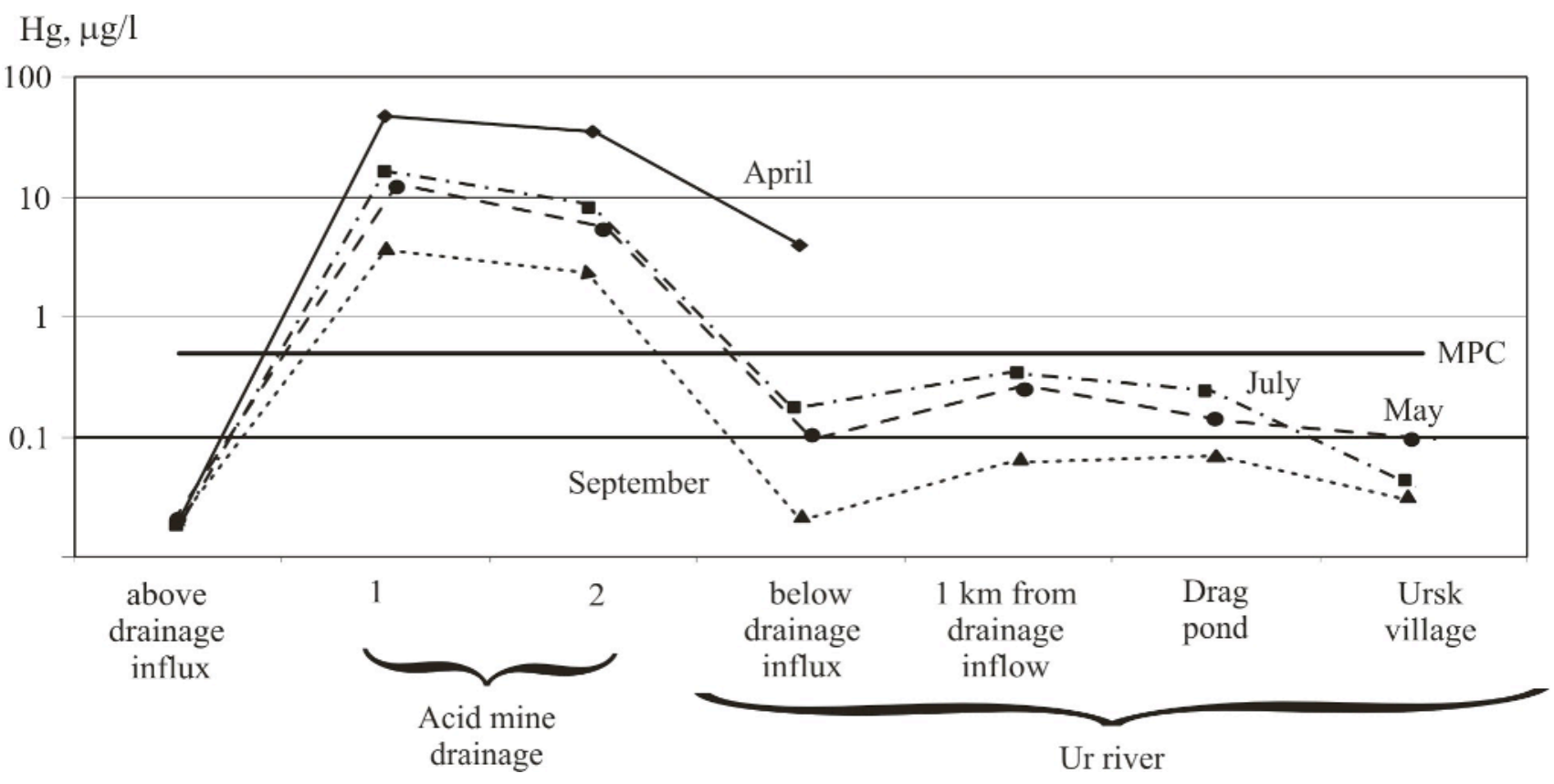

Fig. 1. Seasonal changes of mercury concentration in natural water and acid mine drainage in Ursk waste, were MPC is maximum permissible concentration $(0.05 \mu \mathrm{g} / 1)$.

\section{Results}

In the ravine, where the tailings are located, flows a natural stream, the waters of which are oxidized up to $\mathrm{pH}$ 2 upon interaction with the sulphide matter, and the composition changes from calcium-magnesiumhydrocarbonate to iron-aluminium-sulphate. As the acid mine drainage is neutralized in the environmental water (Ur river), the mineralization increases by 3 times. Content of $\mathrm{Fe}$ in the environmental water increases by 40 times, Al by 20 times, sulphate ion - by 3 times. $5 \mathrm{~km}$ downstream from the confluence point of the river and the acid mine drainage the composition of water reduces to environmental water. Total $\mathrm{Hg}$ in the $\mathrm{Ur}$ river varies depending on season (Fig. 1).

Concentration of mercury in the acid mine drainage directly below the tailing amounts to $47 \mu \mathrm{g} / \mathrm{l}$ in April and drops to $3 \mu \mathrm{g} / \mathrm{l}$ in September. This is caused by the lowered moisture of waste and a decrease in drainage area during summer. Concentration of mercury in the Ur river after its confluence with the drainage stream drops down to $0.02 \mu \mathrm{g} / \mathrm{l}$, which shows that $\mathrm{Hg}$ is effectively deposited in sediments.

Granulometric differentiation can be observed in the derived matter: heavy and coarse particles are found in proximity to the tailings piles, while the small-grained fractions are prevalent in the greatest observed distance. In the nearest proximity to the tailing (up to $70 \mathrm{~m}$ ), the derived waste matter consists mostly of sand (1$0.01 \mathrm{~mm})$, the sand-silt is mostly observed in the middle territory $(70-150 \mathrm{~m})$, and the silt is prevalent in the distance of $500 \mathrm{~m}$ or more (Fig. 2). Due to the difference in the forces of flood water and rains, one may observe the reprecipitation of sand, silt and organic remains (detrital material) in a vertical pit.

Mercury content in the pore solution of waste matter amounts to $100-160 \mathrm{mg} / \mathrm{L}$ directly near the tailings piles and in the middle part of the derived matter; it decreases to $6 \mathrm{mg} / \mathrm{L}$ in highly permeable sandy material (Fig.2 pit №1). Mercury content is lower in the pore solution of swamp hassocks and buried peat (5-39 mg/L), which may be caused by sorbtion in organic matter. The highest mercury concentrations in pore solution are observed in the zone located in the greatest distance from the tailings piles (up to $1170 \mathrm{mg} / \mathrm{L}$ ), which, on the one hand, may be explained by dilution of sulphides found in the wastes; on the other hand, it may be caused by low permeability of sand-silt material and accumulation of mercury in the solution. Mercury species are distributed unevenly in the derived waste matter of varying sizes, detrital matter of swamp hassocks and buried peat (Fig. 2). Mercury content in admixtures to original minerals, pyrite and barite, generally doesn't exceed $10 \%$ of the total content. The amount of mercury bound to original minerals doesn't exceed $15 \%$ even in the relatively fresh waste matter (Fig. 2, Sample 1-2). Mercury sulphide is distributed in the derived waste matter in a extremely irregular way and is observed in rather specific conditions: firstly, it is preserved in poorly permeable silt material in the distance from the tailings impoundment, which is characterized by high mercury content in the pore solution (Fig. 2, Sample 3-1); secondly, sulphide is found in the zones One may suggest that mercury sulphide either doesn't transform in the described conditions or forms for the second time. In any event, mercury sulphide is usually found in places where the derived matter and the detrital matter are mixed and 


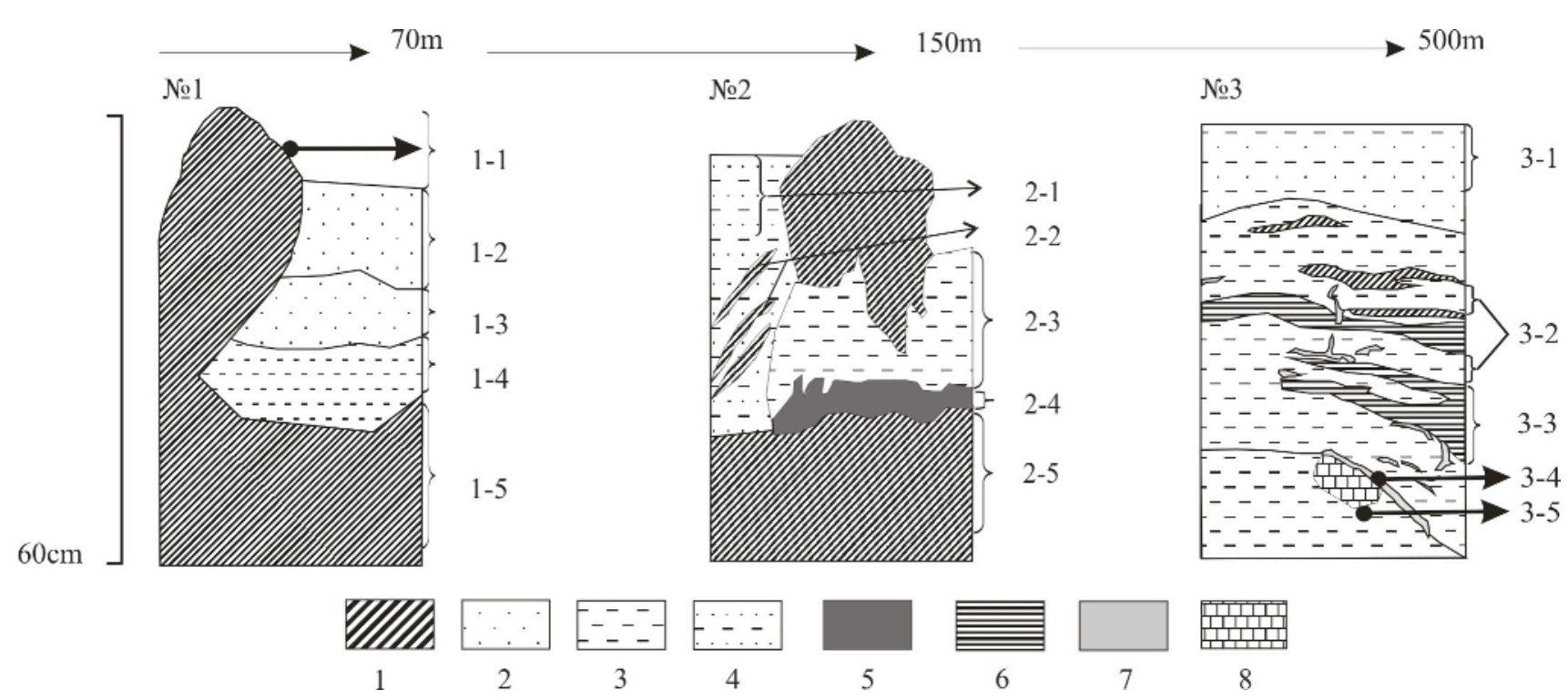

Fig. 2. Vertical sections of transported waste matter at various distances from the Ursk tailing: where 1 is organic matter, 2 - sand matter, 3 - silt matter, 4 - sand-silt matter, 5 - lburied soil, 6- silt matter with organic matter layers , 7 ochreous minerals, 8 - limestone.

thinly layered (Layers 2-2, 3-3). It is possible that mercury is sulphided in anaerobic conditions with the assistance of bacteria; as a result, vermilion is formed as a secondary mineral phase.

Pore solutions in the derived waste matter and the buried peat are highly acidic - sulphate-type ironaluminium with total dissolved solids (TDS) of 6-18 g/L (pH 1-4, Eh 380 - 840 B). Maximum organic carbon content observed in pore solution (obtained from peat hassock material) amounts to $435 \mathrm{mg} / \mathrm{L}$, which speaks of active detrital material destruction on surface by acid drainage solutions. The content of $\mathrm{C}_{\text {org }}$ is notably lower in the pore waters of buried peat: it varies from 24 to $110 \mathrm{mg} / \mathrm{L}$ (Gustaytis M.A., et al, 2010).

\section{Discussion}

A scheme of mercury transformation was proposed on the basis of our investigations, taking both experimental and literary data into account. 4 basic processes (I, II, III and IV) occurring in the dispersion train of the Ursk tailing were specified (Fig. 3).

I. In the wastes of primary ore and ores of the oxidizing zone, mercury is initially found as $\mathrm{HgS}$ and in the form of mineral impurities in primary minerals $-\mathrm{FeS}_{2}$ (pyrite) and $\mathrm{BaSO}_{4}$ (barite). Under the influence of natural processes, it is possible for the oxidation of $\mathrm{HgS}$ in waste material to take place. In aqueous phase and solid phase, containing $\mathrm{SO}_{4}{ }^{2-}$ ion, mercury may be found as $\mathrm{HgSO}_{4}, \mathrm{Hg}^{\circ}, \mathrm{HgSO}_{4} \cdot \mathrm{nH}_{2} \mathrm{O}$. Alongside with that $\mathrm{Hg}$ is evaporated from the waste surface. Sulphide oxidation (e. g. $\mathrm{FeS}_{2}$ ) in waste occurs with the participation of two primary agents - oxygen and Fe (III). Pyrite also serves as a source of $\mathrm{Hg}$ in the solution, as it contains $\mathrm{Hg}$ as a mineral impurity.

II. As a result of diffusion of dissolved organic matter in waste matter transported by floodwater to the swampy ravine area, conditions were created for the formation of the organic $\mathrm{Hg}$ compounds. The process of penetration of surface hassocks and buried peat by $\mathrm{Hg}$ occurred simultaneously. Literary sources show that the optimal conditions for the process of $\mathrm{Hg}$ biomethylation are $\mathrm{pH}<7, \mathrm{Eh}-\geq 0.5 \mathrm{~B}, \mathrm{~T}=20-70^{\circ} \mathrm{C}$, the presence of organic remains, as well as fulvoacids (Kuzubova et al.2000). Such conditions are met in the ravine, where the sulphide-containing matter of the Ursk tailing interacts with the peat matter $\left(\mathrm{pH}=2-4, \mathrm{Eh}=0.6-0.8 \mathrm{~B}, \mathrm{~T}=20-70^{\circ} \mathrm{C}\right.$, $\left.\mathrm{C}_{\text {org }}=20-400 \mathrm{mg} / \mathrm{L}\right)$. As a result, methylmercury is actively formed and accumulated in the ravine territory polluted by the Ursk tailing matter characterized by high mercury and organic matter concentrations.

III. In zones where the organic matter is mixed with the waste matter, large quantities of $\mathrm{HgS}$ are observed. It is possible that such conditions lead to the dimethylation of mercury, causing the formation of a volatile compound - dimethylmercury, which shifts to gaseous phase; at the same time, the formation of $\mathrm{HgS}$ as secondary product is also highly likely. An important condition for this process is the presence of hydrogen sulfide in the natural system, which is formed as a result of transformation in the presence of sulphate-reducing bacteria from sulphate-ion (Craig P.J, 1980).

IV. Along with the processes of mercury compound transformation, sorption of mercury (as $\mathrm{HgX}_{2}$ and $\mathrm{CH}_{3} \mathrm{HgX}$ ) also occurs on $\mathrm{Fe}$ and $\mathrm{Al}$ hydroxides, which are formed upon contact of waste matter and limestone stored in the Ur river valley; consequentially, minerals like plaster-stone, goethite, hydrargillite are formed (Scherbakova I. N. et al, 2011). The same process is observed as a result of neutralization of iron-aluminiumsulphate acid mine drainage and calcium-magnesiumhydrocarbonate water of the Ur river. 


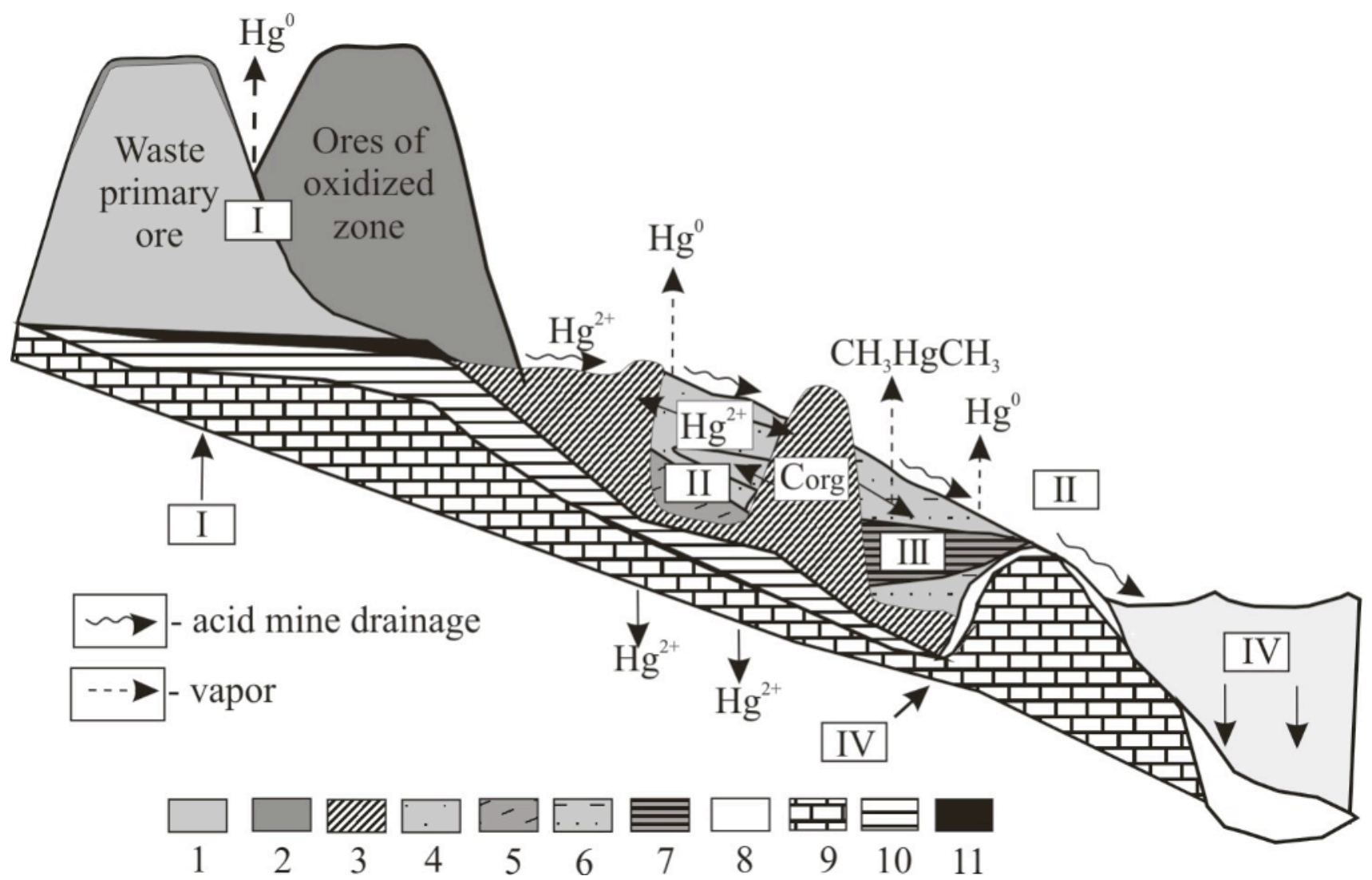

Fig. 3. Scheme of mercury species transformation in Ursk waste, where 1 is primary ore, 2 - ores of oxidizing zone, 3 organic matter, 4 - sand matter, 5 - silt matter, 6 - sand-silt matter, 7 - silt matter with organic matter layers, 8 - spot of Fe and Al hydroxide formation, 9 - limestone, 10 - loam, 11 - land-buried soil.

\section{Acknowledgements}

Research was performed with the support of the RFBR №10-05-00370-a №11-05-01020-a, and grant OPTEC

\section{References}

Arinushkina E. V. Manual for the Chemical Analysis of Soils. Ed. 2. Moscow State University, Moscow, 1970. 488 p. [in Russia].

Gustaytis M. A., Lazareva E. V., Bogush A. A., Shuvaeva O. V., Scherbakova I. N., Polyakova E. V., Badmaeva Zh. O., Anoshin G. N. Distribution of Mercury and its Species

in the Zone of Sulphide Tailing Doklady Eath Science, 2010 Vol 432, №5, PP.655-659.

Scherbakova I. N. Gustaytis M. A., Lazareva E. V., Bogush A. A. Behaviour of heavy metals
$(\mathrm{Cu}, \mathrm{Pb}, \mathrm{Zn}, \mathrm{Fe}, \mathrm{Cd})$ in diffuse halo Ursk tailing (Ursk village, Kemerovo region, Russia)// Chemistry for Sustainable Development №18 PP. 621-633 [in Russia]

Shuvaeva O. V., Gustaytis M.A., Anoshin G.N. Mercury speciation in environmental solid samples using thermal release technique with atomic absorption detection // Anal. Chim. Acta, (2008) Vol 621 P 148-154.

Kuzubova L. I., $\quad$ Shuvaeva O. V., Anoshin G. N. Methylmercury in the Environment (Distribution, Formation in Nature, Determination Methods). An Analytical Review. SPSTL SB RAS, SB RAS Institute of Inorganic Chemistry. Novosibirsk, 2000. $82 \mathrm{p}$ [in Russia].

Craig P.J. Metal cycles and biological methylation.//The natural Environment and the biochemical cycles. Vol.1, Part A (1980) pp.169-227. 